\title{
Resurrecting social infrastructure as a determinant of urban tuberculosis control in Delhi, India
}

\author{
Shivani Chandra ${ }^{1 *}$, Nandini Sharma ${ }^{2 \dagger}$, Kulanand Joshi $^{3 \dagger}$, Nishi Aggarwal $^{4 \dagger}$ and Anjur Tupil Kannan ${ }^{5+}$
}

\begin{abstract}
Background: The key to universal coverage in tuberculosis (TB) management lies in community participation and empowerment of the population. Social infrastructure development generates social capital and addresses the crucial social determinants of TB, thereby improving program performance. Recently, there has been renewed interest in the concept of social infrastructure development for TB control in developing countries. This study aims to revive this concept and highlight the fact that documentation on ways to operationalize urban TB control is required from a holistic development perspective. Further, it explains how development of social infrastructure impacts health and development outcomes, especially with respect to TB in urban settings.
\end{abstract}

Methods: A wide range of published Government records pertaining to social development parameters and TB program surveillance, between 2001 and 2011 in Delhi, were studied. Social infrastructure development parameters like human development index along with other indicators reflecting patient profile and habitation in urban settings were selected as social determinants of TB. These include adult literacy rates, per capita income, net migration rates, percentage growth in slum population, and percentage of urban population living in one-room dwelling units. The impact of the Revised National Tuberculosis Control Program on TB incidence was assessed as an annual decline in new TB cases notified under the program. Univariate linear regression was employed to examine the interrelationship between social development parameters and TB program outcomes.

Results: The decade saw a significant growth in most of the social development parameters in the State. TB program performance showed 46\% increment in lives saved among all types of TB cases per 100,000 population. The 7\% reduction in new TB case notifications from the year 2001 to 2011, translates to a logarithmic decline of 5.4 new TB cases per 100,000 population. Except per capita income, literacy, and net migration rates, other social determinants showed significant correlation with decline in new TB cases per 100,000 population.

Conclusions: Social infrastructure development leads to social capital generation which engenders positive growth in TB program outcomes. Strategies which promote social infrastructure development should find adequate weightage in the overall policy framework for urban TB control in developing countries.

Keywords: Decline in new TB cases, Social capital, Social determinants, Social infrastructure, Tuberculosis, Universal coverage, Urban TB

\footnotetext{
* Correspondence: chandras@rntcp.org

†Equal contributors

${ }^{1}$ Office of the World Health Organization (WHO) Representative to India,

WHO Country Office, New Delhi 110011, India

Full list of author information is available at the end of the article
} 


\section{Background}

Over the past decade, there have been important advances in the global fight against tuberculosis (TB) and towards achievement of the Millennium Development Goals. The global TB response has become more equitable by placing patients at the centre of treatment, prevention, and care. In the year 2006, the World Health Organization (WHO) and the Stop TB Partnership articulated the impact targets for TB cases and deaths in context with the United Nations Millennium Development Goals [1]. With the annual rate of decline in incident TB cases at $1.3 \%$ globally and $2.2 \%$ in the South East Asia region [2], the 2015 Millennium Development Goal targets are achievable, but TB elimination by 2050 remains a distant dream [3].

TB has traditionally been considered as an archetypal disease of poverty which tends to involve a disproportionately large number of underprivileged members of society. Therefore, in order to accelerate economic and social growth and consequently reduce the global burden of $\mathrm{TB}$, it is essential to fight $\mathrm{TB}$ and poverty together. The inequities in health in terms of affordable access to quality care services and the avoidable health inequalities in terms of standardised care practices arise because of the circumstances in which people live and grow. As TB is a medical condition with significant social dimensions, it is essential therefore, that while addressing health equity, any systematic framework for assessment of health care must look beyond medical excellence as good health means not only to reduce suffering but to expand a person's life in order to be able to do what $\mathrm{s} / \mathrm{he}$ wishes to achieve.

In order to accelerate the annual rate of decline in TB incidence required for TB elimination, concomitant efforts need to be made towards implementation of pro-poor, pro-health policies addressing health inequalities. Ambit of health care services which encompass socio-economic arrangements is vital for the universal health coverage mandate which preludes the achievement of the Millennium Development Goals [4].

\section{Caring for urban TB}

The United Nations estimates that the world's urban population will grow by 2 billion before 2030 [5], with a large part of this growth focusing in the unplanned urban slums. Continuous inflow of migrants and mushrooming of unauthorized colonies in slum dwellings have increased the vulnerability of health risks among the urban poor. This, coupled with the fact that TB disease has medical and social implications, highlight the role of social development in improving program performance in an urban area.

\section{Delhi demographic profile}

In India, urbanization is fast becoming the defining process in shaping the course of social transformation, though the urban advantage evades the urban poor, which form one fourth of India's population. Delhi, the capital city of India, is one of the largest urban agglomerations with more than 16 million population (Table 1). The phenomenal population growth in Delhi is predominantly due to large scale migration in the State as a consequence of which half of Delhi's population lives in slums and other urban poor habitation. Besides this influx, around two million commuters visit Delhi every day, primarily for education and employment. The unprecedented growth in the slum population indirectly

\section{Table 1 Demographic profile and TB program} performance of Delhi for the years 2001 and 2011

\begin{tabular}{|c|c|c|}
\hline Delhi demographic profile ${ }^{a, b}$ & Year 2001 & Year 2011 \\
\hline Delhi population & $13,850,507$ & $16,753,235$ \\
\hline Decadal growth rate & $47.0 \%$ & $21.0 \%$ \\
\hline Net migration rate & $12.7 \%$ & $17.5 \%$ \\
\hline Population density (per square km) & 9,340 & 11,297 \\
\hline Sex ratio (Females per 1,000 males) & 821 & 866 \\
\hline Literacy rates (\%) & 82 & 86 \\
\hline Per capita income (INR) & 38,864 & 148,608 \\
\hline Urban Delhi profile $^{c}$ & Year 2001 & Year 2011 \\
\hline Population living in urban areas & $93.0 \%$ & $97.5 \%$ \\
\hline Population growth rate in urban areas & $51.3 \%$ & $26.6 \%$ \\
\hline Population living in one-room dwelling units & $38.1 \%$ & $32.2 \%$ \\
\hline Average number of household members & 4.9 & 5.2 \\
\hline Slum population residing in urban areas & $15.7 \%$ & $19.6 \%$ \\
\hline $\begin{array}{l}\text { Unauthorized settlements (shanty clusters/ } \\
\text { unauthorized/resettlement colonies) }\end{array}$ & $67.5 \%$ & $46.0 \%$ \\
\hline TB program performance in Delhi ${ }^{\text {d }}$ & Year 2001 & Year 2011 \\
\hline $\begin{array}{l}\text { Percentage of State Government budget } \\
\text { on health }\end{array}$ & 7 & 12 \\
\hline $\begin{array}{l}\text { Number of doctors in government hospitals } \\
\text { per } 10,000 \text { population }\end{array}$ & 1.9 & 3.8 \\
\hline Number of treatment centres (DOT centres) & 51 & 585 \\
\hline Number of private sector engagements & 10 & 231 \\
\hline Number of TB suspects examined & $153220^{*}$ & 164392 \\
\hline $\begin{array}{l}\text { Number of new TB case notification rates } \\
\text { per } 100,000 \text { population }\end{array}$ & 229 & 214 \\
\hline TB death rates (\%) & 3.1 & 2.2 \\
\hline Number of lives saved (all types of TB patients) & 4775 & 9076 \\
\hline $\begin{array}{l}\text { Lives saved (all types of TB patients) per } \\
100,000 \text { population }\end{array}$ & 35 & 51 \\
\hline
\end{tabular}

Data Source: ${ }^{a}$ Office of the Registrar General and Census Commissioner, Ministry of Home Affairs, Government of India. ${ }^{b}$ Office of the Registrar General and Census Commissioner, Ministry of Home Affairs, Government of India. 'Urban Health Division, Ministry of Health and Family Welfare, Government of India. ${ }^{d}$ Revised National Tuberculosis Control Program Delhi, Government of National Capital Territory of Delhi (http://www.dotsdelhi.org/programperformance.php) *Data available from the year 2005 onwards in Annual TB Report, 2006 at the website of Revised National Tuberculosis Control Program, Government of India (http://www.tbcindia.nic.in/pdfs/Annual\%20Report\%20TB \%202006.pdf). 
reflects on the poverty, substandard living conditions, and marginalization from basic health services [6]. This has put tremendous pressure on urban infrastructure in the State to provide access to basic public amenities to its residents. As health demands not only health care but also other factors such as economic and social arrangements and the fact that the health system alone does not possess the tools to solve all its health challenges, the Government of Delhi took a call for an epistemic approach to healthcare thus defining the need for good governance initiatives which promote the development of social infrastructure.

\section{Social infrastructure development in Delhi}

Social infrastructure denotes the services and processes which enhance community capacity [7]; it includes development in health (individual and family health), education, information, housing, employment, art and culture, transport and public safety. There has been a substantial increase in social development parameters, such as growth in health and education infrastructure, in Delhi since the year 2000. Several initiatives of the State Government are geared towards creating effective partnerships with community groups for the development and management of the social infrastructure. One of the major initiatives towards building the community capacity in Delhi is the 'Bhagidari' (Partnership) program rolled out by the Government of Delhi in the year 2000 with Resident Welfare Associations (Neighbourhood Communities) for the improvement of education, health, and civic amenities in their locality.

The Bhagidari program is a participatory governance initiative which promotes Government-Community-Citizen engagement under its framework to make the systems more responsive to its citizens $[8,9]$. The Bhagidars, or partners, represent local residents and vulnerable people. The involvement of citizens in the policy framework has led to development of sense of ownership by the citizens, a shift of mind-sets from that of 'Government as Provider' to 'people as empowered'. It has taken the initiative of 'partnering in governance' with a progressive work-culture of 'let's work together' and has produced new collective actors of local associations and popular social groups. In this initiative, residents act as active partners in decision making, they discuss issues affecting effective delivery of civic services with government representatives, and propose a local plan of action pertaining to the desired civic need. In addition to participatory governance, during the small-scale consultative meets and large-scale interactive forums, Bhagidars are informed about the several initiatives rolled out by the State Government for the social security and welfare of residents. With the community getting actively involved through Bhagidari programs, other social sector initiatives by the State Government, such as the 'Mission Convergence' scheme ${ }^{\mathrm{a}}$ for collaboration with civil society and various government departments, illness assistance schemes like the 'Delhi Arogya Nidhi Scheme ${ }^{\text {b }}$, several demand-based interventions like the 'Ladli' scheme ${ }^{\mathrm{c}}$ for incentivizing mandatory education of the girl child, 'Rashtra Swasthya Bima Yojana'd which is a national health insurance scheme that reduces out-ofpocket expenditure for health care and lessens considerable financial burden on the poorest of the poor, and 'Janani Suraksha Yojana' which is a conditional cash transfer scheme that incentivizes women to give birth in health facilities, have all received enhanced advocacy and outreach among the beneficiaries. This has also helped a substantial number of TB patients to get benefits from these social protection schemes [10]. The Bhagidari program is the process for social infrastructure development; the program was extended to all slums of Delhi in the year 2007 through the 'Sanjha Prayas' initiative under the Bhagidari program and through collaboration with existing social welfare schemes. By 2011, approximately 2,000 citizen groups were involved as decision-making actors, representing more than four million of Delhi's population. The framework in Figure 1 explains the mechanism adopted for public participation in the Bhagidari program.

\section{Social capital generation from social infrastructure development}

The main essence of Social Capital is that it refers to the trust, civic norms, and networks that enable collective action and improve market performance by reducing transaction costs $[11,12]$. It is the fundamental requirement for any health equity intervention package intending to address wider public health needs. Thus, it's inclusion in a social sector program yields clear benefits [13]. Social infrastructure includes a wide range of activities and facilities which support the formation of social capital; building social infrastructure is integral to the development of sustainable communities [14]. The participatory governance concept as introduced through the Bhagidari program leads to group participation, building trust and confidence, self-reliance, and income generation in the community. This causes an improved standard of living leading to social infrastructure development and growth in social determinants, which further strengthens social capital. Social capital generated through social infrastructure development provides a platform for community intervention to resolve issues related to health and civic amenities in the locality, thus building stronger communities.

The study supports social infrastructure development underscoring utilization, access, equity, and community empowerment for urban TB control in developing countries. The present paper attempts to study the interrelationship between social infrastructure development and TB program impact in Delhi. Social infrastructure development 


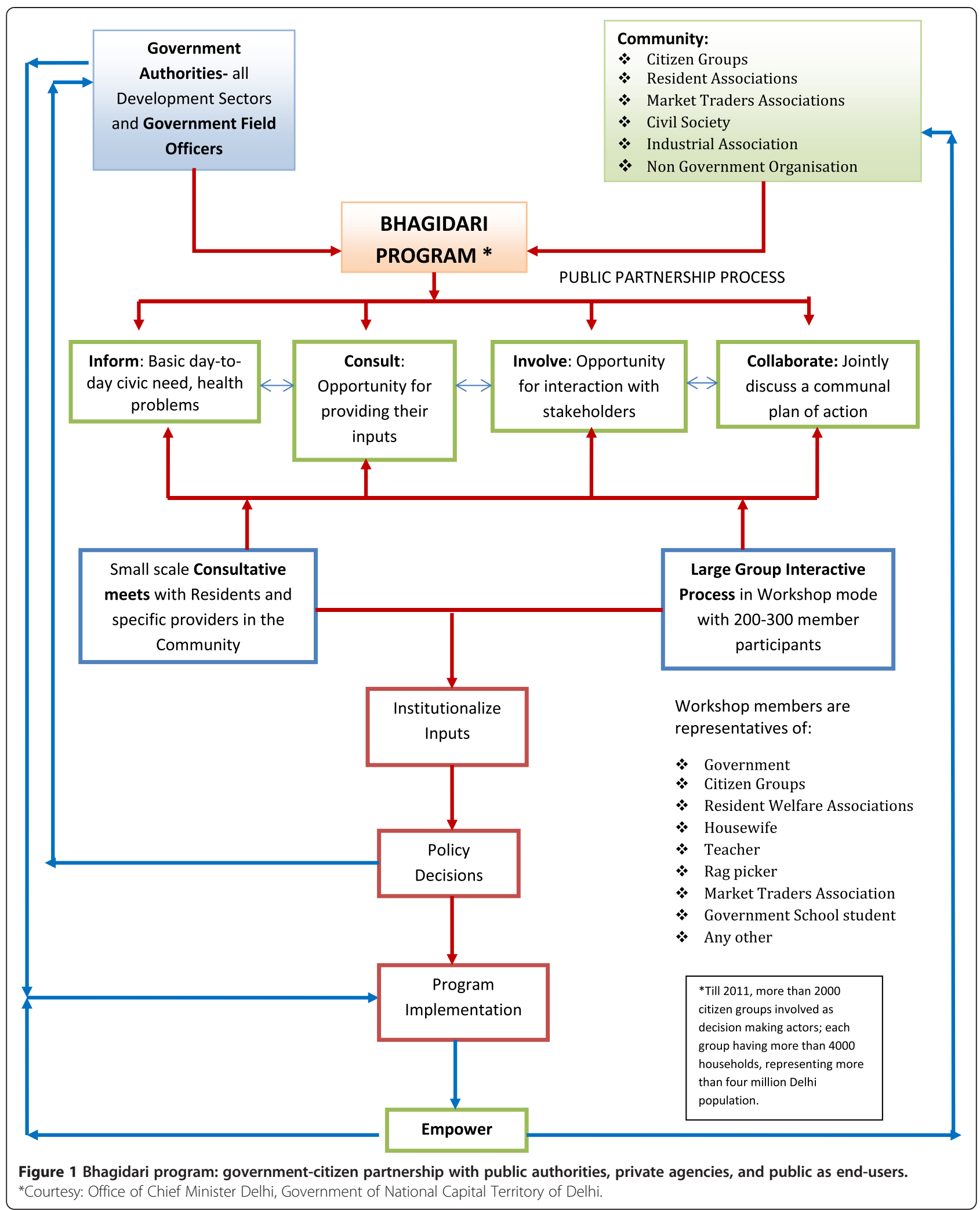

parameters, such as the human development index (HDI) along with other indicators reflecting patient profile and habitation in urban settings, were selected as social determinants of TB. These include adult literacy rates, per capita income, net migration rates, percentage growth in slum population, and percentage of urban population 
living in one-room dwelling units. The study was conducted with an objective to understand the correlation between decline in new TB cases and social sector growth in the State of Delhi.

\section{Methods}

Data was compiled from program surveillance records of new TB patients registered each year under the Revised National TB Control Program, Delhi. Published records of the Government of National Capital Territory of Delhi and the Government of India were used to study the selected social determinants of TB between the years 2001 and 2011 in Delhi.

\section{TB impact indicator}

The TB impact indicator used in the study is the annual rate of decline in new TB cases per 100,000 population [15]. Measurement of new TB cases is based on the WHO policy package for calculating rates of TB incidence, which states that in countries where TB programs have focused on a systematic approach for assessing the quality and coverage of TB surveillance data, then the data from program records is 'certified' as a direct measure of $\mathrm{TB}$ incidence and is a close proxy for $\mathrm{TB}$ incidence in the area [16]. Consequently, the logarithmic rate of decline in TB over successive years of program implementation per 100,000 population was calculated based on the TB incidence values from country program surveillance data for the State of Delhi [17].

\section{Measure of social infrastructure development}

Social infrastructure development was studied in context with social capital generation. Being a multifaceted concept, social capital cannot be symbolized by any single direct indicator [18]. Therefore, in the study, social determinants which pose as indirect indicators of social capital, such as HDI, along with indicators reflecting patient profile and habitation in slums, such as adult literacy rates ( $>7$ years age), per capita income, net migration rates, percentage growth in slum population, and percentage of urban population living in one-room dwelling units have been chosen as a measure of social development. The indicators used for the analysis have been compiled from published database of the Government of India and the Government of National Capital Territory of Delhi [19-23]. The HDI for Delhi was 0.687 and 0.740 for the years 1996 and 2006, respectively, ranking it fourth in the country. The average annual national HDI growth rate (percentage) is 1.56 and the HDI growth rate for Delhi has been computed based on the national HDI projections. Though not included in the analysis, government effectiveness was also studied to understand the role of a stable government towards holistic sustainable development.

\section{Interrelationship between TB impact and social development}

After controlling for the impact HIV on TB incidence, univariate linear regressions were carried out to illustrate the relationships between each independent and dependent variable. Independent variables chosen were HDI, adult literacy rates, per capita income, net migration rates, percentage growth in slum population, and percentage of urban population living in one-room dwelling units and the dependent variable analysed was new TB cases per 100,000 population. Significance in univariate correlation was defined as $\mathrm{r}^{2}>0.2$ and $P<0.05$ two-tailed. SPSS Version 16 (Copyright SPSS Inc.) was used for the analysis.

\section{Results}

\section{Impact of the TB program in Delhi}

Investigation of TB surveillance records identified 492,683 cases of all forms of TB registered in the Revised National TB Control Program Delhi between the years 2001 and 2011. There was an increment of $46 \%$ lives saved among all types of TB cases per 100,000 population between 2001 and 2011. In numbers, this amounts to 9,076 lives saved in 2011 as against 4,775 lives saved in 2001. In Delhi, declining trends were observed in new TB case notification rates during the study period. The number of new TB cases notified under the Revised National Tuberculosis Control Program steadily declined from 229/100,000 population in 2001 to $214 / 100,000$ population in 2011 , a decline of $7 \%$ over ten years since 2001. During the study period, the logarithmic decline in new TB (all forms of TB) patients was at the rate of 5.41 TB cases per 100,000 population in Delhi (Table 2, Figure 2a, b). The logarithmic decline in incidence of new smear positive (infectious) TB patients was found to be significantly higher as compared to the logarithmic rate of decline in all forms of new TB patients.

\section{Interrelationship between TB impact and social development in Delhi}

Correlation and univariate linear regressions were carried out to illustrate the interrelationship between decline in new TB cases and social determinants of TB. Tables 3 and 4 summarize the analysis results.

The social determinants which showed significant association with decline in new TB cases were HDI (negative association), percentage growth in slum population (negative association), and percentage of urban population living in one-room dwelling units (positive association). Adult literacy rates and per capita income showed a non-significant negative association with the decline in new TB cases. Net migration rate though positively associated, was not a significant predictor of decline in new TB cases during the study period. 
Table 2 Decline in new TB patients (all forms of TB) and new smear-positive TB patients per 100,000 population; Delhi, 2001-2011

\begin{tabular}{|c|c|c|c|c|c|c|c|c|}
\hline \multicolumn{5}{|c|}{$\begin{array}{l}\text { New TB patients (all forms of TB) per 100,000 } \\
\text { population' registered under the Revised } \\
\text { National TB Control Program in Delhi (2001-2011) }\end{array}$} & \multicolumn{4}{|c|}{$\begin{array}{l}\text { New smear positive TB patients per } 100,000 \\
\text { population }{ }^{c} \text { registered under the Revised } \\
\text { National TB Control Program in Delhi }(2001-2011)\end{array}$} \\
\hline Year & $\begin{array}{l}\text { New TB } \\
\text { patients }^{\mathrm{a}}\end{array}$ & $\begin{array}{l}\text { Rate } \\
\text { (per 100,000) }\end{array}$ & $\begin{array}{l}95 \% \text { Confidence } \\
\text { interval }( \pm)\end{array}$ & $\begin{array}{l}\text { Log } \\
\text { rate }\end{array}$ & $\begin{array}{l}\text { New smear positive } \\
\text { TB patients }{ }^{\mathrm{b}}\end{array}$ & $\begin{array}{l}\text { Rate } \\
\text { (per 100,000) }\end{array}$ & $\begin{array}{l}\text { 95\% Confidence } \\
\text { interval ( } \pm \text { ) }\end{array}$ & $\begin{array}{l}\text { Log } \\
\text { rate }\end{array}$ \\
\hline $2001-2002$ & 31,718 & 229.84 & 2.53 & 5.437 & 11,794 & 85.46 & 1.54 & 4.448 \\
\hline $2002-2003$ & 31,856 & 229.18 & 2.54 & 5.435 & 12,119 & 87.19 & 1.56 & 4.468 \\
\hline 2003-2004 & 34,121 & 229.00 & 2.62 & 5.434 & 12,384 & 83.11 & 1.58 & 4.420 \\
\hline 2004-2005 & 33,155 & 215.29 & 2.59 & 5.372 & 12,604 & 81.84 & 1.60 & 4.405 \\
\hline 2005-2006 & 34,778 & 217.36 & 2.65 & 5.382 & 12,554 & 78.46 & 1.59 & 4.363 \\
\hline 2006-2007 & 36,873 & 229.03 & 2.73 & 5.434 & 13,717 & 85.20 & 1.66 & 4.445 \\
\hline 2007-2008 & 38,261 & 230.49 & 2.78 & 5.440 & 13,768 & 82.94 & 1.67 & 4.418 \\
\hline 2008-2009 & 37,532 & 219.49 & 2.75 & 5.391 & 14,002 & 81.88 & 1.68 & 4.405 \\
\hline 2009-2010 & 39,222 & 222.85 & 2.81 & 5.407 & 14,207 & 80.72 & 1.69 & 4.391 \\
\hline \multirow[t]{8}{*}{ 2010-2011 } & 37,655 & 213.99 & 2.76 & 5.354 & 13,245 & 75.26 & 1.66 & 4.336 \\
\hline & & & Average & 5.408 & & & Average & 4.410 \\
\hline & & & Slope & -0.005 & & & Slope & -0.009 \\
\hline & & & Standard deviation & 0.003 & & & Standard deviation & 0.003 \\
\hline & & & 95\% Confidence interval $( \pm)$ & 0.014 & & & $\begin{array}{l}95 \% \text { Confidence } \\
\text { interval }( \pm)\end{array}$ & 0.015 \\
\hline & & & Pearson's coefficient & -0.557 & & & Pearson's coefficient & -0.749 \\
\hline & & & $P$ value & $0.050^{*}$ & & & $P$ value & $0.006^{* *}$ \\
\hline & & & (one-tailed) & & & & (one-tailed) & \\
\hline
\end{tabular}

Notes. *P $<0.05$ level, ${ }^{* *} \mathrm{P}<0.01$ level.

Data Source ${ }^{\mathrm{a}, \mathrm{b}}$ Program surveillance records, Revised National Tuberculosis Control Program, Government of National Capital Territory of Delhi and Central TB Division, Ministry of Health and Family Welfare, Government of India.

Data Source ${ }^{\mathrm{C} C e n s u s ~ o f ~ I n d i a, ~ O f f i c e ~ o f ~ t h e ~ R e g i s t r a r ~ G e n e r a l ~ a n d ~ C e n s u s ~ C o m m i s s i o n e r, ~ M i n i s t r y ~ o f ~ H o m e ~ A f f a i r s, ~ G o v e r n m e n t ~ o f ~ I n d i a . ~}$

HDI and percentage growth in slum population showed significant negative correlation with new TB cases per 100,000 population, indicating that an increase in HDI and percentage growth in slum population tends to cause a significant reduction in number of new TB cases. Percentage of urban population living in one-room dwelling units showed significant positive correlation to new TB cases, which suggests that residents of crowded dwellings have higher incidence of TB. There was no significant association with literacy rates and per capita income indicating that it is ostensibly more important to be aware than educated and that TB is not only a disease of the poor. Net migration rates, though positively correlated, were not significant, which suggests that migration has no effect on TB incidence in the State.

\section{a}

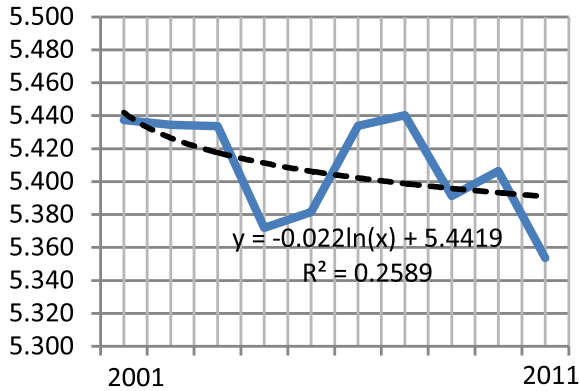

b

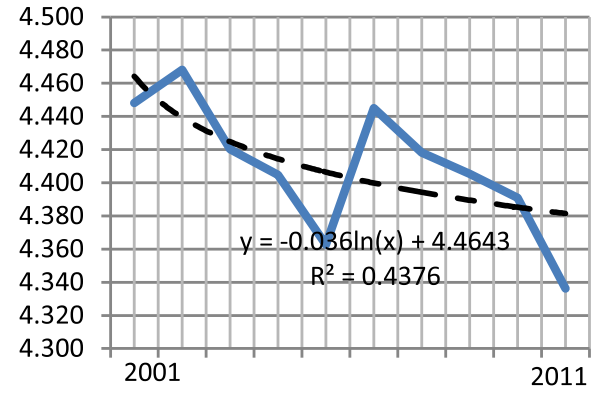

Figure 2 Logarithmic decline in tuberculosis (TB) notification rate per 100,000 population; Delhi, 2001-2011. (a) New TB patients; (b) New smear-positive TB patients. 
Table 3 Correlation matrix: endogenous and exogenous TB variables in Delhi from 2001-2011 $(n=10)$

\begin{tabular}{|c|c|c|c|c|c|c|c|c|}
\hline Parameters & & $\begin{array}{l}\text { Human } \\
\text { development } \\
\text { index }\end{array}$ & $\begin{array}{l}\text { Literacy } \\
\text { rates }\end{array}$ & $\begin{array}{l}\text { Per capita } \\
\text { income }\end{array}$ & $\begin{array}{l}\text { New TB cases } \\
\text { per } 100,000 \\
\text { population }\end{array}$ & $\begin{array}{l}\text { Net } \\
\text { migration } \\
\text { rates }\end{array}$ & $\begin{array}{l}\text { Percentage } \\
\text { growth } \\
\text { in slum } \\
\text { population }\end{array}$ & $\begin{array}{l}\text { Percentage of } \\
\text { urban population } \\
\text { living in one-room } \\
\text { dwelling units }\end{array}$ \\
\hline \multirow{2}{*}{$\begin{array}{l}\text { Human development } \\
\text { index }\end{array}$} & Pearson correlation & 1 & $0.951^{* *}$ & $0.981^{* *}$ & $-0.846^{*}$ & -0.340 & $0.998^{* *}$ & $-0.998^{* *}$ \\
\hline & Sig. (two-tailed) & & 0.004 & 0.001 & 0.03 & 0.51 & 0.001 & 0.001 \\
\hline \multirow[t]{2}{*}{ Literacy rates } & Pearson correlation & $0.951^{* *}$ & 1 & $0.934^{* *}$ & -0.784 & -0.435 & $0.957^{* *}$ & $-0.956^{* *}$ \\
\hline & Sig. (two-tailed) & 0.004 & & 0.006 & 0.06 & 0.39 & 0.003 & 0.003 \\
\hline \multirow[t]{2}{*}{ Per capita income } & Pearson correlation & $0.981^{* *}$ & $0.934^{* *}$ & 1 & -0.774 & -0.222 & $0.989^{* *}$ & $-0.990^{* *}$ \\
\hline & Sig. (two-tailed) & 0.001 & 0.006 & & 0.071 & 0.672 & 0.001 & 0.001 \\
\hline \multirow{2}{*}{$\begin{array}{l}\text { New TB cases per } \\
100,000 \text { population }\end{array}$} & Pearson correlation & $-0.846^{*}$ & -0.784 & -0.774 & 1 & 0.538 & $-0.846^{*}$ & $0.844^{*}$ \\
\hline & Sig. (two-tailed) & 0.03 & 0.06 & 0.071 & & 0.27 & 0.03 & 0.03 \\
\hline \multirow[t]{2}{*}{ Net migration rates } & Pearson correlation & -0.340 & -0.435 & -0.222 & 0.538 & 1 & -0.333 & 0.328 \\
\hline & Sig. (two-tailed) & 0.51 & 0.39 & 0.672 & 0.27 & & 0.52 & 0.53 \\
\hline \multirow{2}{*}{$\begin{array}{l}\text { Percentage growth } \\
\text { in slum population }\end{array}$} & Pearson correlation & $0 \cdot 957^{* *}$ & $0.957^{* *}$ & $0.989^{* *}$ & $-0.846^{*}$ & -0.333 & 1 & $-0.999 * *$ \\
\hline & Sig. (two-tailed) & 0.003 & 0.003 & 0.001 & 0.03 & 0.52 & & $1.122 \mathrm{E}-09$ \\
\hline \multirow{2}{*}{$\begin{array}{l}\text { Percentage of urban } \\
\text { population living in } \\
\text { one-room dwelling } \\
\text { units }\end{array}$} & Pearson correlation & $-0.998^{* *}$ & $-0.956^{* *}$ & $-0.990^{* *}$ & $0.844^{*}$ & 0.328 & $-0.999^{* *}$ & 1 \\
\hline & Sig. (two-tailed) & 0.001 & 0.003 & 0.001 & 0.03 & 0.53 & 1.122E-09 & \\
\hline
\end{tabular}

$* P<0.05$ level, ${ }^{* * P}<0.01$ level.

As detailed in Table 4, univariate regression showed that HDI and percentage growth in slum population had significant negative regression weights with the dependent variable. One-room dwelling units showed positive regression weights while literacy rates, per capita income, and net migration rates showed no significant contribution to the new TB cases in the State. The results of univariate linear regression suggest that a significant proportion of new TB cases could be predicted by HDI levels (negative association), percentage growth in slum population (negative association), and one-room dwelling units (positive association) in the State. Translating it into numbers,
0.887 new TB cases will decrease in the city with every one point increase in HDI $(P<0.05)$. Additionally, the $\mathrm{r}^{2}$ values indicate that approximately $72 \%$ of the variation in new TB cases is predicted by HDI levels, which is a composite assessment of standard of living (health index, literacy index, and income index) in a community. Similar results were observed with percentage growth in slum population, indicating that a significant reduction in new TB cases is associated with one unit increase in slum population $(P<0.05)$. A significant positive association was observed with percentage of population living in one-room dwelling units and new TB cases $(P<0.05)$.

Table 4 Univariate linear regression: impact of social determinants on number of new TB cases per 100,000 population in Delhi during the years 2001-2011

\begin{tabular}{|c|c|c|c|c|c|c|c|}
\hline \multirow[t]{2}{*}{ Social predictors } & \multirow[t]{2}{*}{$r^{2}$} & \multirow[t]{2}{*}{$F$} & \multicolumn{2}{|c|}{ Unstandardized coefficient } & \multirow{2}{*}{$\begin{array}{l}\text { Standardized coefficient } \\
\text { Beta }\end{array}$} & \multirow[t]{2}{*}{$t$} & \multirow[t]{2}{*}{ Sig. } \\
\hline & & & B & Standard error & & & \\
\hline Human development index & 0.716 & 10.08 & -0.886 & 0.279 & -0.846 & -3.17 & $0.03^{*}$ \\
\hline Literacy rates & 0.62 & 6.4 & 0.401 & 0.877 & 0.462 & 1.344 & 0.311 \\
\hline Per capita income & 0.774 & 5.98 & -0.139 & 0.057 & -0.774 & -2.447 & 0.071 \\
\hline Net migration rates & 0.289 & 1.63 & 0.025 & 0.02 & 0.538 & 1.27 & 0.27 \\
\hline Percentage growth in slum population & 0.716 & 10.08 & -0.043 & 0.013 & -0.846 & -3.17 & $0.03^{*}$ \\
\hline $\begin{array}{l}\text { Percentage of urban population living in } \\
\text { one-room dwelling units }\end{array}$ & 0.712 & 9.89 & 0.012 & 0.003 & 0.843 & 3.14 & $0.03^{*}$ \\
\hline
\end{tabular}

Notes. ${ }^{*} \mathrm{p}<0.05$, Dependent Variable: Number of New TB Cases per 100,000 population. 
With regards to literacy rate, per capita income, and net migration rate variables, no significant associations could be detected to the dependent variable. The insignificant positive regression weights shown by literacy rates indicate that level of awareness is more essential than literacy status for availing TB care services. Per capita income showed non-significant negative regression weights, suggesting that rising income level has little or no impact on TB disease. Similarly, net migration rates showed no significant contribution to new TB cases in the community. However, the effect of migration on disease burden (which includes both new and previously treated cases) requires further study.

\section{Discussion}

Through this study we get a clear message that there is an inherent synergy between social infrastructure development and TB program impact in Delhi. As shown, exogenous factors, such as social determinants of $\mathrm{TB}$, supplement endogenous factors, such as TB program performance, thus complementing each other's efforts towards TB control dynamics.

One of the consequences of rapid urbanization in the developing world is the continuous growth of slums. Many health outcomes are worse in slums than in neighbouring urban areas or even rural areas. Over the years, growth in cities has affected several socio-demographic and economic factors in urban communities. Poor housing conditions and overcrowding are synonymous with slum dwellings and have been implicated in the spread of TB [24]. Due to the inability to plan for adequate social infrastructure in urban areas, these problems have also aggravated. In Delhi's scenario, it was observed that a rise in slum population had a significant effect on the decline of new TB patients. This suggests that the holistic social development achieved due to growth in social infrastructure under the Bhagidari initiative has been instrumental in resolving issues related to health and civic amenities in the slum areas of the city.

In addition, it has also been observed that people who live in the same house with a TB patient are at greatest risk of exposure to TB [25]. In an essay on slum health [26], the authors have suggested to harness the existing resident structure and social capital for provision of basic services in slum dwellings. One such initiative for involvement of residents in the neighbourhood is the Bhagidari approach, detailed in this study.

Another exogenous factor which affects TB incidence is migration. Several studies performed in countries like New Zealand [27], United States [28], and Singapore [29], have shown that the prime reason for TB incidence not decreasing in these countries is the migration of TBinfected people from high incidence countries, a finding which was not observed in the Delhi scenario. Sound prevention strategies which involve communities in the improvement of the health of migrants instead of focusing on their parent birth place have previously been suggested [30]; this fact gets restated herein. Migration has shown no effect on new TB cases in the city; this reaffirms the need to focus on delivering a holistic package of services to all residents through social capital initiatives which instil community participation.

In 2002, Singh et al. [31] suggested the need for extensive health education by community involvement to create awareness about TB in the slum communities of Delhi. Although literacy rates did not contribute to the correlation matrix in our study, the positive regression weights indicate that a level of awareness is more essential than literacy status for availing TB program services.

It is notable that the largest impact of any public health intervention is at the community level [32]. The WHO Commission on Social Determinants of Health advocates community development as one of the theme areas of intervention for ensuring equity in population health [33]. Researchers have suggested that inter-sectoral collaboration, along with community participation, is essential for achieving equity in program performance and health outcomes [34]. Their report emphasizes the fact that the final fight for equity rests with the public sector. Despite the predominance of the private health sector in urban cities, it has been observed that the health needs of the socio-economically disadvantaged section of the population are rarely met by them. Invariably, this burden is shouldered by the public health sector, the performance of which depends upon the development of social infrastructure. This implies that countries like India with a large public sector hub will have the maximum impact on population health through community development strategies. Building community capacity will ensure substantial progress in the Government's effort to promote equity for all, as has been observed in the Delhi scenario.

The notion that addressing social determinants through community involvement corrects health inequities in a community is not just rhetoric but a reality, requiring workable ideas for action. Several authors [35,36] have posited the need for research on community-based interventions to understand the biological and social phenomena driving the TB epidemic. Partnerships which involve actors from within and beyond the health sector will facilitate a better understanding of the process of linking social determinants to TB. The community participation approach emphasized in this study reiterates the involvement of residents as third partners leading to improved health and development outcomes, especially with respect to $\mathrm{TB}$.

Researchers have tried to explore the causal mechanism behind the positive relationship between social capital generation and TB program outcomes. In their 
study on correlation between social capital and TB, Holtgrave and Crosby [37] have suggested that social capital is highly predictive of TB program outcomes. Regression models have established the synergy between social determinants and TB impact indicators, especially TB incidence [38]. In countries like Bangladesh, Senegal, Thailand, and Zambia, the rate of decline in TB has been attributed to social sector reforms [39]. This reflects the need for several exogenous factors to work in tandem in order to affect the social and health outcomes in an area [40]; our study also corroborates these findings.

The study surmises that adoption of a meso-level public-private interface fosters collaboration between all principal actors (public authorities, private sector, and the public as an end-user) in the community. Researchers have ascertained that partnerships which use third party interface show a higher contribution to $\mathrm{TB}$ case detection [41]. Having seen the challenges faced by the TB program in urban areas with weak public health infrastructure and huge out-of-pocket expenditures, the TB program policy makers are exploring new strategies to leverage public-private partnerships with the help of public-private interface agencies for collaboration with various providers in urban settings. It is extremely important that while drafting such strategies, the public as end-users are engaged in the policy framework for improved acceptability and better monitoring of these services. Though extensive leverage for supply-side markets are in vogue globally, it is equally important to have a demand-side empowerment for further leveraging these initiatives without which there will be equity deficit in service delivery.

\section{Recommendations}

Emerging from this discussion is the fact that a holistic approach addressing social determinants in an urban set-up is sine qua non for TB control. The significance of social infrastructure development as a positive catalyst for achieving broader public policy outcomes in urban TB control requires renewed attention and resurrection by researchers for its adoption in policy design. Thus, a strong policy inducement promoting social infrastructure development under a decentralized administrative initiative like the Bhagidari program needs to be acknowledged in the public health policy framework for urban TB control in the developing world.

Planning and provision of social infrastructure needs coproduction and collaboration with various sectors. The study strongly echoes that caring for urban TB does not necessarily imply a separate system setup, but a need to develop an integrated model by collaborating with existing partners for sustainability. Researchers [42,43] have identified a set of parameters which could be incorporated in the TB program monitoring indicators at service delivery level. Based on the observations of this study, few systemic interventions are recommended for urban TB control in developing countries (Table 5). These interventions will not only enhance the program's performance by harnessing the community's potential but will also help in making the social opportunities more accessible to TB patients in addition to the availability of health services. A schematic framework depicting the synergy between social infrastructure development and urban TB control has been developed on the basis of the above recommendations (Figure 3 ).

\section{Conclusions}

The TB control program worldwide is sincere about addressing the universal health coverage mandate. Therefore, it is essential that program policymakers take cognizance of the fact that in addition to the primacy of public-funded provision and private sector collaboration, explicit strategies for the holistic systemic intervention to health care needs to be drafted by empowering the community first. It is important that strategies which promote social infrastructure development initiatives having a positive impact on $\mathrm{TB}$ control, gain momentum to find adequate weightage in the overall policy framework.

\section{Limitations of the study}

Being a metropolitan city with a floating denominator as its population estimates, the number of cases belonging to a specified cohort may not denote the same population. In addition, there are a substantial number of TB cases in the community which are not reported under the program surveillance records. A rough sketch of approximate numbers of such unreported cases could be drawn based on expert opinion; however, to use it for the calculation of decline in disease incidence from the year 2001 would be erroneous and hence not attempted. Nevertheless, it is acknowledged as a limiting factor for further debate.

In the study, ecological analysis has not been attempted; analysis is limited to the program records and published data. Thus, the findings may not represent a true correlation between individual social reform and active TB. Despite these caveats, the synergy between social sector reforms and success of the TB program emerges as a potent force of TB control in urban settings.

\section{Endnotes}

${ }^{\mathrm{a}}$ Mission Convergence Program, started by Government of Delhi in the year 2008, is an attempt at holistic planning for social service delivery. With a view to smoothen the process of implementation across various welfare 
Table 5 Shift in systemic intervention for urban TB control in developing countries

\begin{tabular}{|c|c|}
\hline Thrust areas & Work plan \\
\hline \multirow[t]{3}{*}{ Strengthen social capital } & $\begin{array}{l}\text { - Adopt community intervention strategies which support development } \\
\text { of social infrastructure }\end{array}$ \\
\hline & $\begin{array}{l}\text { - Create opportunities to encourage people's participation in decision-making } \\
\text { and community activities }\end{array}$ \\
\hline & $\begin{array}{l}\text { - Collaborate with elected representatives and community self-help groups for the } \\
\text { public health responsibility of their community }\end{array}$ \\
\hline \multirow[t]{11}{*}{ Collaborate with existing service providers } & $\begin{array}{l}\text { - Liaison with the Ministry of Urban Development for Urban Self Employment } \\
\text { program, Urban Women Self Help programs. Availability of night shelters for the } \\
\text { shelterless population }\end{array}$ \\
\hline & $\begin{array}{l}\text { - Work with the Department of Education to advocate TB in school health } \\
\text { programs and youth awareness clubs }\end{array}$ \\
\hline & $\begin{array}{l}\text { - Facilitate provision of social protection through available National Health Insurance } \\
\text { schemes for below poverty line families and senior citizens. Development of a } \\
\text { sustainable program for daily wagers with the Department of Labour }\end{array}$ \\
\hline & $\begin{array}{l}\text { - Coordinate with the Food and Supplies Department for access to subsidized } \\
\text { public distribution system }\end{array}$ \\
\hline & - Link with mother and child health services and support networks \\
\hline & - Establish innovative schemes in public-private partnership \\
\hline & $\begin{array}{l}\text { - Reduce out-of-pocket expenses incurred by people on transport and wage loss by } \\
\text { linking with available Social Welfare programs, especially for commuters from } \\
\text { satellite towns bordering the city }\end{array}$ \\
\hline & - Explore the utilization of existing physical infrastructure for community services \\
\hline & $\begin{array}{l}\text { - Seek opportunities to participate in city development plans and in planning for } \\
\text { improvement of medical infrastructure in secondary/tertiary institutes }\end{array}$ \\
\hline & $\begin{array}{l}\text { - Liaison with the Department of Information and Technology to improve access } \\
\text { to digital technology }\end{array}$ \\
\hline & $\begin{array}{l}\text { - Share best practices with other public health programs to reach out to the } \\
\text { vulnerable and marginalized groups in the city }\end{array}$ \\
\hline \multirow[t]{5}{*}{ Stress on affirmative inclusion in TB program } & - 'Search TB' in vulnerable and high risk groups among city dwellers \\
\hline & - Mandatory TB notification by all sectors \\
\hline & $\begin{array}{l}\text { - Support incorporation of basic socio-economic data of patients in TB program } \\
\text { surveillance records }\end{array}$ \\
\hline & - Develop social inclusion as a separate standard in the International Standards of TB care \\
\hline & - Incorporate available social welfare schemes in Patient Charter for TB care \\
\hline
\end{tabular}

schemes, the Government of Delhi has initiated several steps towards redirecting the governance system so that there is a clear focus on service delivery and enhancement of system efficiency. The most prominent of these steps include a redefinition of the poor into a holistic category of the vulnerable, a targeted vulnerability survey, introduction of electronic beneficiary cards, and a unique public-private partnership at the community level and setting up single window facilitation centres called the Gender Resource Centres - 'Samajik Suvidha Kendras'. The latter are to work for both empowerment and survey facilitation. This flagship program of the Delhi Government aims to make Delhi a more inclusive city by integrating the existing social security schemes and delivering them through a unified structure in a decentralized manner. More information about this program can be found at http://delhi.gov. in/wps/wcm/connect/DoIT_MC/doit_mc/home.
${ }^{b}$ Delhi Arogya Nidhi Scheme is a State Illness Assistance fund which provides financial assistance to poor patients suffering from life threatening disorders for their treatment in government hospitals (broadly in line with guidelines set by Government of India in the year 1996). By 2011, financial assistance of over INR 200 million has been given to seriously ill patients belonging to below the poverty line in Delhi. More information about the scheme can be found at http://www.delhi.gov. in/wps/wcm/connect/doit_health/Health/Home/Delhi+ Arogya+Nidhi.

${ }^{\mathrm{c}}$ Laadli Scheme is a demand-based intervention for incentivizing mandatory education of the girl child. The scheme was launched in Delhi in 2008 to empower girls by linking financial assistance with their education up to senior secondary level. Since 2008, 275,651 girls have been registered and have availed the financial benefits of 


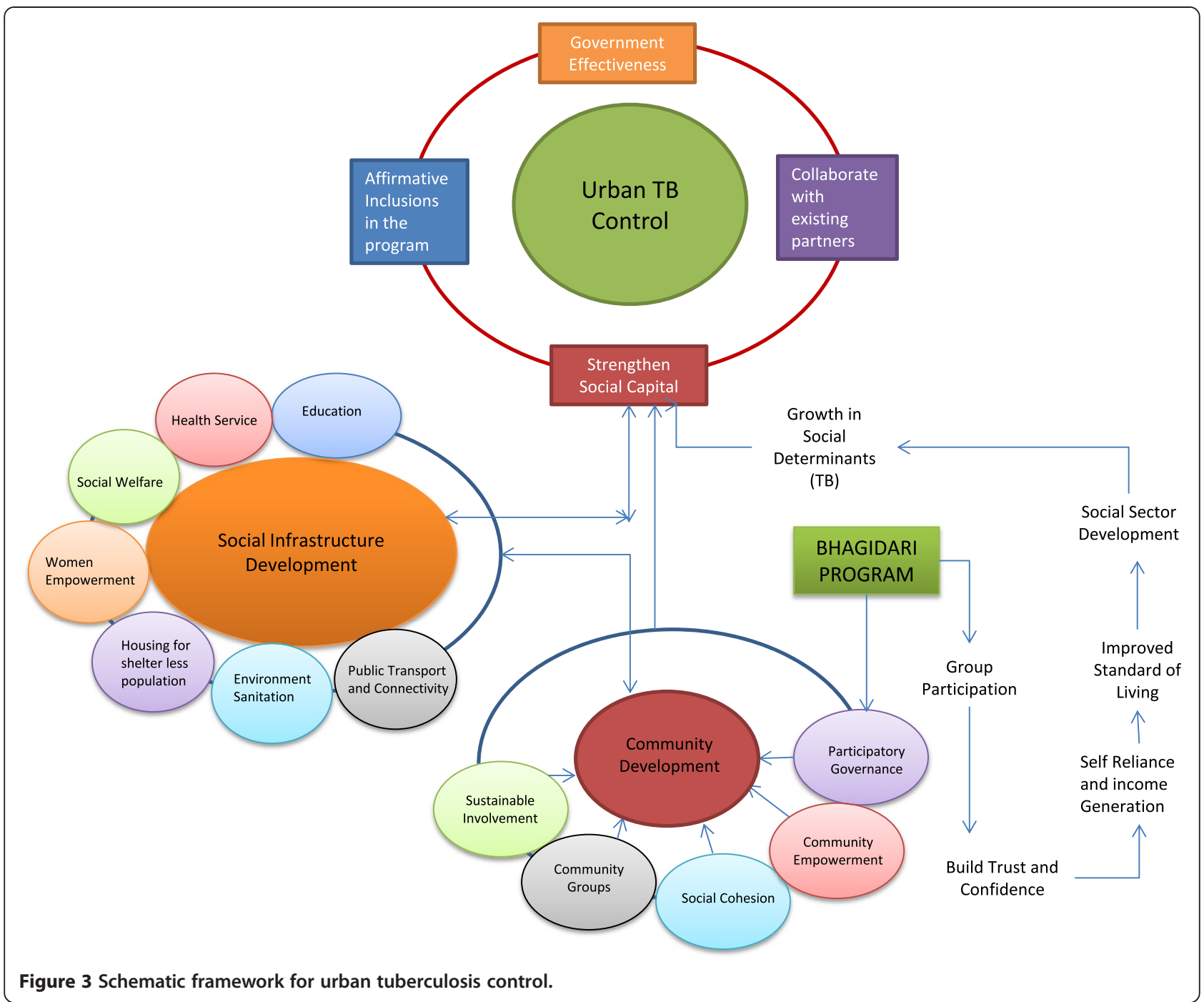

this scheme in Delhi. In the first year of its roll out, the number of female births in Delhi registered per 1,000 boys born increased to 1,004 girl registrations; an increase of $18 \%$ from the year 2007. More information about this scheme can be found at http://delhi.gov. in/wps/wcm/connect/doit_wcd/wcd/Home/Delhi+Ladli+ Scheme/.

${ }^{\mathrm{d}}$ Rashtra Swasthya Bima Yojana is a National health insurance scheme that reduces out-of-pocket expenditure for health care and lessens considerable financial burden on the poorest of the poor. It has helped build the quality chasm in health care delivery as it empowers beneficiaries by providing them with an electronic smart card worth INR 30,000 and empanels hospitals that comply with standard guidelines. More information about this insurance scheme can be found at http://www.delhi.gov. in/wps/wcm/connect/DOIT_Labour/labour/related+links/ rashtriya+swasthya+bima+yojana/.
${ }^{\mathrm{e} J a n a n i}$ Suraksha Yojana is a conditional cash transfer scheme that incentivizes women to give birth in health facilities. More information about the scheme can be found at http://delhi.gov.in/wps/wcm/connect/doit health/Health/Home/Family+Welfare/RCH+Programmes/.

${ }^{\mathrm{f}}$ Sanjha Prayas is an initiative that was rolled out in 2007 under the Bhagidari program to provide a hygienic atmosphere in Delhi slum clusters. For this purpose, the scheme for providing Financial Assistance to MultiPurpose Cooperative Societies was rolled out by the Delhi Government. It was envisioned that through this scheme, the Delhi Government would rehabilitate poor people living in slum clusters by providing financial assistance to slum dwellers for their relocation from their existing place or to carry out economic promotional activity at their existing place. More information can be found at http://delhiplanning.nic.in/Write-up/ 2006-07/V-I/3.pdf. 


\section{Abbreviations}

HDI: Human development index; TB: Tuberculosis; WHO: World Health Organization.

\section{Competing interests}

The authors declare that they have no competing interests.

\section{Authors' contributions}

The study was conceptualized and designed by SC. The original protoco was written by SC and then developed in consultation with NS and KJ. Data collection and analysis was performed by SC supported by NA and NS. Critical review was made by AK, during the several iterations of the manuscript. All authors have approved the final version of the paper. All authors confirm that the manuscript has not been published in any journal or other citable forms.

\section{Acknowledgements}

We thank the Office staff of Honourable Chief Minister of Delhi for their inputs on Social sector development in the State. We are thankful to Shri Anshu Prakash, Joint Secretary, Ministry of Health and Family Welfare, Government of India for his valuable inputs on urban governance. We also thank Dr. K.S. Sachdeva, Additional Deputy Director General TB, Central TB Division, Nirman Bhawan, Government of India, for his valuable inputs on country program perspective in the National Tuberculosis Program performance. We are indebted to Dr. R.P. Vashist, ex-State TB Control Officer Government of Delhi, for sharing the raw data on Revised National TB Control Program from the year 2001 to 2011. The views expressed in this publication are those of the authors and are not influenced by staff of the Bhagidari program or the TB Control program.

\section{Author details}

'Office of the World Health Organization (WHO) Representative to India WHO Country Office, New Delhi 110011, India. ${ }^{2}$ Department of Community Medicine, Maulana Azad Medical College, Government of National Capital Territory of Delhi, New Delhi 110002, India. ${ }^{3}$ Office of Chief Minister Delhi, Government of National Capital Territory of Delhi, New Delhi 110002, India. ${ }^{4}$ Department of Biostatistics, New Delhi TB Centre, New Delhi 110002, India. ${ }^{5}$ Department of Community Medicine, University College of Medica Sciences, Government of National Capital Territory of Delhi, New Delhi 110095, India.

Received: 19 May 2013 Accepted: 4 January 2014 Published: 17 January 2014

\section{References}

1. World Health Organization: The Stop TB Strategy: Building on and Enhancing DOTS to Meet the TB Related Millennium Development Goals. Geneva: World Health Organization; 2006. http://www.who.int/tb/publications/2006/stop_ tb_strategy.pdf Accessed May 27, 2012.

2. World Health Organization: Global Tuberculosis Control - Epidemiology, Strategy, Financing. Geneva: World Health Organization; 2012. http://www. who.int/tb/publications/global_report/en/. Accessed June 20, 2012.

3. Lönnroth K, Jaramillo E, Williams BG, Dye C, Raviglione M: Drivers of tuberculosis epidemics: the role of risk factors and social determinants. Soc Sci Med 2009, 68(12):2240-2246.

4. World Health Report: Health Systems Financing - The Path to Universal Coverage. Geneva: World Health Organization; 2010. http://whqlibdoc.who. int/whr/2010/9789241564021_eng.pdf Accessed October 2, 2012.

5. United Nations Secretariat: Department of Economic and Social Affairs, Population Division. World Urbanization Prospects The 2011 Revision. New York: United Nations; 2012

6. United Nations Human Settlement Programme UN-Habitat 2003: The Challenge of Slums - Global Report on Human Settlements 2003. Kenya: Earthscan Publications Ltd; 2003. http://www.unhabitat.org/pmss/getElectronic Version.aspx?nr=1156\&alt=1 Accessed July 15, 2012.

7. Casey S: Establishing Standards for Social Infrastructure. Queensland, University of Queensland: UQ Boilerhouse Community Engagement Centre; 2005.

8. Government of National Capital Territory of Delhi: Bhagidari - The Concept. Available at http://archive.is/kHSQt Accessed July 10, 2011.
9. United Nations Secretariat: Department of Economic and Social Affairs. Good Practices and Innovations in Public Governance United Nations Public Service Awards 2003-2011. New York: United Nations; 2011.

10. Government of National Capital Territory of Delhi: Social Welfare Department; 2012. http://delhi.gov.in/wps/wcm/connect/doit_socialwelfare/ SocialWelfare/Home/ Accessed August 12, 2012.

11. The World Bank: Social Capital. http://web.worldbank.org/WBSITE/ EXTERNAL/TOPICS/EXTSOCIALDEVELOPMENT/EXTTSOCIALCAPITAL/O contentMDK:20642703 menuPK:401023 pagePK:148956 piPK:216618 theSitePK:401015,00.html Accessed April 15, 2012.

12. Kjellstrom T, Mercado S: Towards action on social determinants for health equity in urban settings. Environ Urbaniz 2008, 20(2):551-574.

13. World Health Organization: Centre for Health Development. Our cities, our health, our future. In Report to the WHO Commission on Social Determinants of Health. Japan: World Health Organization; 2008. http://www. who.int/social_determinants/resources/knus_final_report_052008.pdf Accessed August 7, 2012.

14. National Capital Region Planning Board Ministry of Urban Development, Government of India: Social Infrastructure Sector in the National Capital Region; 2010. http://ncrpb.nic.in/social_infra.php Accessed August 12, 2012

15. World Health Organization: Global Tuberculosis Control Report. Geneva: World Health Organization; 2011. http://www.who.int/tb/publications/ global_report/2011/en/index.html Accessed June 20, 2012

16. World Health Organization: TB impact measurement: policy and recommendations for how to assess the epidemiological burden of TB and the impact of TB control. In Stop TB Policy Paper; no.2. WHO/HTM/TB/ 2009.416. Geneva: World Health Organization; 2009. http://whqlibdoc.who. int/publications/2009/9789241598828_eng.pdf Accessed August 12, 2011.

17. Central TB Division: RNTCP Status Report 2001-2011 Directorate General of Health Services, Ministry of Health and Family Welfare, Government of India. http://www.tbcindia.nic.in/ Accessed May 21, 2012.

18. Ostrom E: Social capital: a multi-faceted perspective. In Social Capital: A Fad or a Fundamental Concept?. Edited by Dasgupta P, Serageldin I. Washington, DC: World Bank; 2000:172-214.

19. Census of India: Office of the Registrar General and Census Commissioner, Ministry of Home Affairs, Government of India. In Census 2001 - Data Summary and Census 2011; Provisional Population Totals (districts/su-districts) National Capital Territory of Delhi. http://censusindia.gov.in/ Accessed February 24, 2012

20. Delhi Development Authority: Ministry of Urban Development, Government of National Capital Territory of Delhi. In Master Plan New Delhi 2021. http://dda.org.in/planning/master_plans.htm Accessed March 15, 2012

21. Ministry of Women and Child Development Government of India: United Nations Development Program India and Indian Institute of Public Administration. In Gendering Human Development Indices: Recasting the Gender Development Index and Gender Empowerment Measure for India. Part 1,2,3. New Delhi; 2009. http://wcd.nic.in/publication/GDIGEReport/Part3.pdf. Accessed June 14, 2012.

22. Department of Planning: Government of National Capital Territory of Delhi. India: Economic Survey of Delhi 2001-2002 and 2008-2009. http://delhi.gov.in/wps/ wcm/connect/DolT_Planning/planning/home Accessed September 7, 2012.

23. National Building Organisation: Ministry of Housing and Urban Poverty Alleviation, Government of India, Report of the Committee on Slum Statistics/ Census. New Delhi; 2011. http://mhupa.gov.in/W_new/Slum_Report_NBO.pdf Accessed September 12, 2012

24. Wanyeki I, Olson S, Brassard P, Menzies D, Ross N, Behr M, Schwartzman K Dwellings, crowding, and tuberculosis in Montreal. Soc Sci Med 2006, 63(2):501-511

25. Baker M, Das D, Venugopal K, Howden-Chapman P: Tuberculosis associated with household crowding in a developed country. J Epidemio/ Community Health 2008, 62(8):715-721.

26. Unger A, Riley LW: Slum health: from understanding to action. PLoS Med 2007, 4(10):1561-1566

27. Das D, Baker M, Venugopal K, McAllister S: Why the tuberculosis incidence rate is not falling in New Zealand. N Z Med J 2006, 119(1243):U2248.

28. Cain KP, Benoit SR, Winston CA, MacKenzie WR: Tuberculosis among foreign-born persons in the United States. JAMA 2008, 300(4):405-412.

29. Kyi Win KM, Chee CB, Shen L, Wang YT, Cutte J: Tuberculosis among foreign-born persons, Singapore, 2000-2009. Emerg Infect Dis 2011. 17(3):517-519. 
30. Littleton J, Park J, Thornley C, Anderson A, Lawrence J: Migrants and tuberculosis: analysing epidemiological data with ethnography. Aust N Z J Public Health 2008, 32(2):142-149.

31. Singh MM, Bano T, Pagare D, Sharma N, Devi R, Mehra M: Knowledge and attitude towards tuberculosis in a slum community of Delhi. J Commun Dis 2002, 34(3):203-214.

32. Frieden TR: A framework for public health action: the health impact pyramid. Am J Public Health 2010, 100(4):590-595.

33. Commission on Social Determinants of Health: Closing the Gap in a Generation: Health Equity Through Action on the Social Determinants of Health. Final Report of the Commission on Social Determinants of Health Geneva: World Health Organization; 2008.

34. Blas E, Sommerfeld J, Kurup AS: Social Determinant Approaches to Public Health: From Concept to Practice. Geneva: World Health Organization; 2011.

35. Lönnroth K, Castro KG, Chakaya JM, Chauhan LS, Floyd K, Glaziou P, Raviglione MC: Tuberculosis control and elimination 2010-50: cure, care, and social development. Lancet 2010, 375(9728):1814-1829.

36. Hargreaves JR, Boccia D, Evans CA, Adato M, Petticrew M, Porter JD: The social determinants of tuberculosis: from evidence to action. Am J Public Health 2011, 101(4):654-662.

37. Holtgrave DR, Crosby RA: Social determinants of tuberculosis case rates in the United States. Am J Prev Med 2004, 26(2):159-162.

38. Oxlade O, Schwartzman K, Behr MA, Benedetti A, Pai M, Heymann J, Menzies D: Global tuberculosis trends: a reflection of changes in tuberculosis control or in population health? Int J Tuberc Lung Dis 2009, 13(10):1238-1246.

39. Jahan S, McCleery R: Making Infrastructure Work for the Poor. Synthesis Report for Four Country Studies: Bangladesh, Senegal, Thailand and Zambia. New York: United Nations Development Program; 2005. http://www.undp.org/ content/dam/aplaws/publication/en/publications/poverty-reduction/ poverty-website/making-infrastructure-work-for-the-poor/ MakingInfrastructureWorkforthePoor.pdf Accessed October 12, 2012.

40. Holland DP, Person AK, Stout JE: Did the 'Great Recession' produce a depression in tuberculosis incidence? Int J Tuberc Lung Dis 2011, 15(5):700-702

41. Lal SS, Sahu S, Wares F, Lönnroth K, Chauhan LS, Uplekar M: Intensified scale-up of public-private mix: a systems approach to tuberculosis care and control in India. Int J Tuberc Lung Dis 2011, 15(1):97-104.

42. Dye C, Lönnroth K, Jaramillo E, Williams BG, Raviglione M: Trends in tuberculosis incidence and their determinants in 134 countries. Bull World Health Organ 2009, 87(9):683-691.

43. Rasanathan K, Kurup A, Jaramillo E, Lönnroth K: The social determinants of health: key to global tuberculosis control. Int I Tuberc Lung Dis 2011, 15(6):S30-S36.

doi:10.1186/1478-4505-12-3

Cite this article as: Chandra et al:: Resurrecting social infrastructure as a determinant of urban tuberculosis control in Delhi, India. Health Research Policy and Systems 2014 12:3.

\section{Submit your next manuscript to BioMed Central and take full advantage of:}

- Convenient online submission

- Thorough peer review

- No space constraints or color figure charges

- Immediate publication on acceptance

- Inclusion in PubMed, CAS, Scopus and Google Scholar

- Research which is freely available for redistribution

Submit your manuscript at www.biomedcentral.com/submit
C Biomed Central 